\title{
O contrário dos direitos humanos (explicitando Zizek)
}

\section{J. A. LINDGREN ALVES*}

“... não vivemos nós na era dos direitos humanos universais, que se afirmam até mesmo contra a soberania estatal? O bombardeio da Iugoslávia pela OTAN não foi o primeiro caso de intervenção militar realizada em decorrência de pura preocupação normativa (ou, pelo menos, apresentando-se como assim realizada), sem referência a qualquer interesse político-econômico “patológico”. Essa nova normatividade emergente para os 'direitos humanos' é, entretanto, a forma em que aparece seu exato oposto”.

Slavoj Zizek

\section{Pré-introdução que não chega a ser prefácio}

Por mais que hoje se possa imaginar o contrário, quando o grande pensador cult da atualidade, Slavoj Zizek, escreveu que a "nova normatividade emergente para os direitos humanos é a forma em que aparece seu exato oposto", ele não tinha em mente nada a ver com os ataques que destruíram as torres do World Trade Center em Nova York e uma ala do Pentágono em Washington, D.C. Tampouco podia ter ele em mente as ações e disposições legislativas adotadas em seguida pelos Estados Unidos em sua "guerra contra o terrorismo", muitas das quais colocam direitos civis preciosos em sursis e em suspense. O livro em que esse filósofo, psicanalista e crítico cultural esloveno registrou tal frase contundente, no parágrafo aqui reproduzido parcialmente em epígrafe, ${ }^{1}$ fora posto à venda nas livrarias norte-americanas no mesmo ano de 2001, mas vários meses antes do fatídico (em múltiplos significados) Onze de Setembro.

Não se referindo a tendências relacionadas a esses atentados e levando em consideração a relevância sem precedentes que o tema dos direitos humanos havia passado a ter na agenda internacional do pós-Guerra Fria, particularmente por meio de construções normativas contra a impunidade dos grandes violadores, não estaria essa afirmação deslocada no tempo? Não seria ela contraditória com os fatos? 
Que quereria dizer Zizek com “o oposto dos direitos humanos”? A conhecida e desgastada reiteração da inexistência de direitos universais na medida em que estes são criações históricas, originárias de uma cultura específica? Ou, de maneira prosaica, menos principista, a habitual violação sistemática - não seria melhor dizer "sistêmica"? - desses direitos fundamentais, que sem dúvida existem e são de todos?

Tratar-se-ia de frase pour épater do mais novo enfant terrible das ciências sociais? Seu autor não é, com efeito, pensador irreverente de país um tanto exótico, que, não contente de unir Lacan, Hegel e Kant em análises anti-capitalistas, libertárias, supostamente anacrônicas, insiste em não separar a cultura pop e a filosofia ocidental mais erudita? Ou seria por que, europeu periférico de nascença, esse pesquisador balcânico, do Instituto de Estudos Sociais de Ljubljana, teimosamente insiste em ir contra a moda (multi)culturalista dos grandes centros ocidentais irradiadores do pensamento pós-moderno, arraigadamente "perspectivistas" e dissimuladamente relativistas (a serviço voluntário ou involuntário do universalismo "do mercado") para defender com ardor e consciência crítica os valores universais do próprio Ocidente iluminista?

Na seqüência da passagem em que essa frase se insere, Zizek a explicita em contexto filosófico, reinterpretando, com auxílio de Claude Lefort e Jacques Rancière, a posição cética de Marx a propósito dos direitos humanos e da igualdade formal: o abismo escondido por seu enunciado adviria do fato de que a forma não é mera forma. Implica uma dinâmica concreta, contrária à busca de condições para a igualdade universal efetiva, que deixa marcas profundas na materialidade social. ${ }^{2}$ Sem elucubrações desse tipo, mas delas se aproximando ou distanciando às vezes, conforme o caso, o que se pretende aqui é mais simples: avaliar a pertinência dessa afirmação atualmente inusitada à luz das vicissitudes empíricas com que já se vinha defrontando a luta pelos direitos humanos antes mesmo do Onze de Setembro.

\section{Introdução real: progressos e paradoxos}

Quem observava, em meados de 2001, determinados fatos recentes, como a entrega do ex-Presidente Milosevic da Iugoslávia ao Tribunal da ONU na Haia, as iniciativas para levar o General Pinochet a julgamento no Chile (após sua quase extradição da Inglaterra para a Espanha), os processos judiciais externos ou domésticos contra ex-governantes centro e sul-americanos implicados em massacres de civis (casos de ex-dirigentes guatemaltecos e do líder da junta militar argentina Jorge Rafael Videla), assim como o sentenciamento, no Brasil, a 632 anos de prisão, do comandante das tropas da PM que ocuparam a Casa de Detenção do Carandiru no episódio de 1992, poderia ter, muito possivelmente, a sensação de que a situação dos direitos humanos estava se tornando mais promissora no mundo. 
Poderia até, com algum otimismo, acreditar que o caminho para uma verdadeira Justiça Internacional vinha se consolidando, neste início de século, com as sementes lançadas na última década do século passado. Era isso que pareciam apontar, entre outras novidades, as crescentes ratificações do estatuto do Tribunal Penal Internacional aprovado pela Conferência de Roma de 1998, o julgamento pelo Tribunal ad hoc para a ex-Iugoslávia de indiciados croatas e bósnios muçulmanos (em demonstração aparente de que não havia parcialidade anti-sérvia naquele tribunal), os processos da ONU em Arusha ou da justiça belga em Bruxelas contra indivíduos hutus que participaram do genocídio de tutsis de Ruanda em 1995.

Com efeito, e malgrado a rejeição pelos Estados Unidos do Tribunal Penal Internacional, ${ }^{3}$ esse "otimismo judicial" era tão palpável que levara um grupo de 30 juristas de várias nacionalidades, inclusive alguns orientais, a definirem, na Escola Woodrow Wilson de Assuntos Públicos e Internacionais da Universidade de Princeton, uma série de 14 diretrizes, denominadas "Princípios de Princeton” (the Princeton Principles on Universal Jurisdiction), para servirem de orientação aos julgamentos internacionais de indivíduos, ex-Chefes de Estado ou não, responsáveis por crimes que extrapolam jurisdições territoriais. ${ }^{4} \mathrm{E}$ foi esse mesmo otimismo, no que ele tinha de mais ingênuo - ou teria sido, ao contrário, uma fundada desconfiança nos instrumentos desse otimismo o estímulo para submetêlos a teste? -, que inspirara um grupo de advogados ocidentais a apresentarem à promotora do Tribunal Internacional para a ex-Iugoslávia, em abril de 1999, com apoio da Anistia Internacional, pedido de indiciamento dos líderes da OTAN pelos sofrimentos infligidos à população civil da Sérvia durante a guerra do Kossovo (o pedido foi rejeitado com a alegação de que não havia sido feita - e não se poderia fazer - atribuição individual de responsabilidades). ${ }^{5}$

Por mais que se possam questionar as premissas em que se baseavam todas essas novidades judiciais (a seletividade “da ONU” na montagem de tribunais ad hoc, a entrega praticamente "comprada" do ex-Presidente Milosevic ao tribunal da Haia, ${ }^{6}$ a parcialidade na escolha dos ex-dirigentes que se pretende punir nas iniciativas mais conhecidas, a alegada desatenção com a soberania nacional chilena no pedido de extradição de Pinochet pela Justiça espanhola - assim como o fato de a condenação do responsável pela ação da PM contra os prisioneiros rebelados na Casa de Detenção de São Paulo, circunscrito à esfera brasileira e objeto de recurso, não significar ainda o encerramento do caso com punição exemplar), é difícil contestar a importância intrínseca desses fatos. Eles constituíam e constituem ainda passos importantes, de grande simbolismo, para o funcionamento de mecanismos de justiça elaborados pouco a pouco no contexto das Nações Unidas, ou, no que diz respeito ao caso brasileiro aqui mencionado, encaminham-se na direção do atendimento de clamores da cidadania acordes com os direitos humanos e as Regras Mínimas das Nações Unidas para o Tratamento de Prisioneiros (por mais que alguns setores de nossa sociedade tenham, na época do massacre do 
Carandiru, defendido a matança dos presos rebelados como forma legítima de limpeza social).

Se esses e outros fatos, abundantes e significativos, eram - e são ainda inegavelmente positivos para os direitos humanos; se estes direitos se tornaram uma constante no discurso contemporâneo, além de tema de monitoramento internacional autorizado por conferência mundial; 7 se os direitos humanos, na década de 1990, foram pela primeira vez erigidos em justificativa ética para intervenções armadas "desinteressadas" (como afirmavam os líderes da OTAN durante os bombardeios da Iugoslávia na guerra do Kossovo), então faz todo sentido indagar por que motivos tais direitos, reputados universais, são ainda - ou, mais precisamente, são de novo - desconsiderados ou repudiados sob o rótulo legalmente anacrônico, mas culturalmente persistente, com força atual redobrada, de que não passam de manifestação do imperialismo ocidental. ${ }^{8}$

Por que motivo, ao mesmo tempo em que são citados com tanta freqüência em quase todo o planeta, os direitos humanos continuam objeto de tamanha descrença (e tamanho desconhecimento!) de parte daqueles que mais deveriam proteger? Que razões mais ou menos abrangentes do que a conhecida duplicidade (double-standards) dos poderosos nessa matéria teriam levado o mesmo Slavoj Zizek, em outro texto também pré-Onze de Setembro, a identificar nesses direitos uma "ética perversa" (sic), ${ }^{9}$ com significado mais amplo do que o de Marx ao condenar os direitos humanos (do Século XIX) como instrumentos para a legitimação da exploração do trabalhador? Que fundamento concreto, ademais da maciça destruição da Sérvia pela OTAN, embasaria a afirmação interpretativa daquele atual cidadão da República da Eslovênia, um pensador que nunca teve inclinações pró-Sérvia (ou pró-Tito, e, muito menos, pró-Milosevic), de que “a nova normatividade emergente para os 'direitos humanos' é a forma em que aparece seu exato oposto” (o grifo é do próprio Zizek)?

\section{Humanitarismo "para inglês ver”?}

Quando, nos estertores da Guerra Fria, a França, impulsionada pelos Médecins sans Frontières, ${ }^{10}$ submeteu à Assembléia Geral das Nações Unidas, na sessão de 1988, o projeto de resolução sobre assistência humanitária que deu origem à expressão “direito de ingerência”, sua preocupação explicitada era com as dificuldades interpostas por determinados Governos de países conflagrados, como o Afeganistão (de regime secular pró-soviético) e o Sudão (muçulmano sunita fundamentalista, em luta contra os “cristãos” do Sul), à concessão de auxílio médico e alimentar a vítimas integrantes - muitas vezes apenas pela etnia - de movimentos insurrecionais. A Resolução 45/131, em que se transformou o projeto francês, após os debates e questionamentos esperados, foi, não obstante, adotada por consenso. ${ }^{11}$ Sua rationale era, afinal, uma extensão indubitavelmente lógica 
do direito internacional dos direitos humanos, em sua vertente humanitária: o direito elementar de todas as pessoas, vitimadas por cataclisma de origem natural ou humana, de receberem a assistência necessária a sua sobrevivência. Visto por outro ângulo, não o dos titulares individualizados desse direito fundamental, mas o das entidades prestadoras de auxílio, tratava-se do direito das organizações humanitárias, não-governamentais e não-subordinadas ao Comitê Internacional da Cruz Vermelha, de terem acesso às vítimas de qualquer desastre ou conflito, independentemente de sua posição perante o governo do Estado respectivo, para a prestação de assistência. ${ }^{12}$

Desde a adoção dessa resolução, muitas outras, na Assembléia Geral e, em especial, no Conselho de Segurança das Nações Unidas, estenderam enormemente o direito de acesso às vítimas. As do Conselho de Segurança, raramente consensuais, conferiram a esse novo direito, antes não previsto em qualquer ramo disciplinar do Direito Internacional, feições sobretudo militares. Fizeram-no ao avalizar $a$ posteriori ou ao promover $a b$ initio a intervenção de forças armadas estatais em conflitos alheios, com objetivos humanitários - sem definir em termos genéricos, universais e regulamentadores, como é da essência do Direito, as características desse informalmente chamado "direito de ingerência”.

O primeiro exemplo da nova ingerência militar humanitária configurou-se na ação de auxílio e proteção aos kurdos do Iraque, na seqüela da Guerra do Golfo de 1991, envolvendo não somente a contenção bélica das forças de Bagdá para o lançamento de comida e medicamentos por pára-quedas às populações em fuga, como também a proibição, até hoje vigente, de vôos por aeronaves iraquianas em grande parte do espaço aéreo do país. Outras experiências ilustrativas dessa nova modalidade de ingerência autorizada logo se seguiram: na Somália (para o fornecimento de alimentos à população submetida à anomia de uma guerra de clãs devastadora), em países da América Central (para a manutenção da paz e do respeito aos direitos humanos entre forças do Governo e movimentos insurgentes); nas guerras inter-étnicas do território da antiga Iugoslávia (em operações de peaceenforcement, terrivelmente tardias, entre forças militares e paramilitares de diferentes facções micronacionalistas).

Todos esses episódios de intervenção armada contavam com o respaldo da "comunidade internacional”, representada pela ONU, à atuação de Estados e organizações específicas (os Estados Unidos na Somália, a OEA/Estados Unidos no Haiti, a ECOWAS africana na África Ocidental), ou se concretizavam no posicionamento de forças multinacionais diretamente sob a égide das próprias Nações Unidas - os famosos “capacetes azuis” - nas áreas de conflito. Exitosas, como na Namíbia e em El Salvador, ou fragorosamente mal-sucedidas, como na Somália, na Croácia e na Bósnia-Herzegovina, essas iniciativas se regiam por "normas” tão legítimas quanto possível nas condições existentes, porquanto consubstanciadas em resoluções da única instância “constitucional” multilateral - 
por menos eqüitativa que seja a composição do conselho que trata das questões atinentes às ameças à paz e à segurança internacionais. E, embora na Bósnia, a partir do malogro dos chamados "espaços protegidos" (safe havens) como o de Srebenica, as forças de paz da ONU tenham sido autorizadas a usar da força, inclusive aérea, para impor essa malograda "proteção" às populações civis perseguidas, nenhuma dessas operações contemplou a exclusividade de bombardeios aéreos como solução para os problemas de direitos humanos ou direito humanitário.

O primeiro caso recente em que o "humanitarismo" foi decidido "unilateralmente"13 (por aliança militar de que não era membro o Estado-alvo), sem ser levado à consideração das Nações Unidas (fosse porque a OTAN considerasse a Europa sua chasse gardée, fosse porque certamente não haveria apoio de todos os membros permanentes do Conselho de Segurança), foi o da Guerra do Kossovo - na verdade, a guerra da OTAN contra o que sobrara da antiga Iugoslávia (Sérvia e Montenegro), especialmente a Sérvia. Sua justificativa eram as violações de direitos humanos dos kossovares, cidadãos iugoslavos de etnia albanesa, residentes (e crescentemente insurretos) na província sérvia do Kossovo, perpetradas pelos sérvios lá residentes ou para lá transferidos por Belgrado, na condição de refugiados expulsos da Krajina (região do território croata tradicionalmente povoada por sérvios), depois da guerra de secessão da República da Croácia.

Não cabe aqui questionar a veracidade dos informes sobre as atrocidades praticadas pelas partes em conflito no território da ex-Iugoslávia, nem tampouco o nacionalismo agressivo oportunisticamente instigado nas respectivas populações, com efeitos aterradores, por líderes do gênero de um Slobodan Milosevic. ${ }^{14}$ Cabe sim, indagar, como foi possível conceber um combate legítimo em defesa de direitos humanos por meio de bombardeios acionados a milhares de metros de altitude, que sequer visavam claramente instalações, militares ou não, dos responsáveis pelas violações. Cabe, sim, refletir se é possível fundamentar com o Direito e com a Ética uma guerra supostamente "justa” realizada contra alvos quase sempre civis (além de pontes, estradas e usinas, o próprio edifício da emissora de televisão local, numa repetição anacrônica do que haviam feito os soviéticos na Primavera de Praga, com seu notório pavor da liberdade de expressão). Caberia, ainda, perguntar se é aceitável, em nome dos direitos humanos, proteger coletividades por meio de ataques que, ao longo de setenta e oito dias, além de vitimarem cidadãos totalmente desvinculados da prática de massacres, arrasaram, em efeito nãocolateral, as condições de viabilidade do país que os sustentava. ${ }^{15}$

Foi exatamente com os qualificativos de "guerra justa e necessária”, em defesa de "nossos valores”, na proteção de "nossos interesses” e "para avançar a causa da paz”, que o Presidente Bill Clinton explicou aos norte-americanos o início dos ataques aéreos contra a Iugoslávia, acrescentando que "(S)e tivéssemos hesitado, o resultado teria sido um desastre moral e estratégico. Os kossovares 
albaneses ter-se-iam tornado um povo sem pátria, vivendo em condições difíceis em um dos países mais pobres da Europa” (ao que se poderia indagar, depois da rendição iugoslava, se a situação moral e estratégica dos Estados Unidos e da Europa, assim como as condições e perspectivas dos kossovares se tornaram diferentes para melhor). Com discurso parecido e justificativas iguais pronunciaramse os demais líderes da OTAN.

De todas as declarações sobre o assunto feitas em março de 1999, a que se tornou mais famosa foi do Primeiro Ministro britânico, Tony Blair, que definiu elegantemente a emergência de "um novo internacionalismo", de conteúdo estritamente humanitário:

"Estamos lutando por um mundo onde os ditadores não possam mais infligir sofrimentos horrendos a seu próprio povo com o objetivo de continuarem no poder. Entramos num novo milênio em que os ditadores saberão que não podem realizar limpezas étnicas ou reprimir seus povos com impunidade". ${ }^{16}$

Seria muito bom se a certeza expressada nessa afirmação viesse a confirmarse de forma tão convincente que o "novo internacionalismo" pudesse servir de dissuasão efetiva a ditadores mal-intencionados. Seria ainda muito bom se os bombardeios da OTAN tivessem logrado, pelo menos, convencer os próprios albaneses, kossovares ou não, de que o caminho mais adequado para a consecução da não-discriminação étnica, a que todos fazem jus dentro de qualquer território, e da autonomia efetiva alegadamente colimadas na Iugoslávia atual não deveria ser o de retaliações assassinas anti-sérvias no Kossovo "libertado", ou o de novas ações armadas contra alvos na Macedônia - que, evidentemente, nada têm a ver com a figura de Slobodan Milosevic. Seria, ainda, extraordinário se o "novo internacionalismo" fosse capaz de dissuadir o terrorismo fundamentalista, particularmente aquele de caráter suicida, que algum tempo depois iria manifestarse nos atentados em Nova York e Washington, instrumentalizados por aviões de passageiros, e que, de per si ou agravados pela "guerra contra o terrorismo", nos termos em que foi declarada em reação a eles, inauguraria a nova era de pavor em que todos passamos a viver.

Qualquer que tenha sido o valor real dos bombardeios da OTAN contra a reduzida Iugoslávia, não é necessário duvidar das convicções humanitárias expressadas na época pelos líderes da aliança atlântica. É verdade inconteste que o Governo Milosevic já havia apoiado, estimulado e praticado muitos horrores na Croácia e na Bósnia (embora a recíproca dos adversários também fosse verdadeira), não faltando indicações de que eles se repetiriam na província irrequieta do Kossovo, de maioria albanesa. Tampouco é necessário dar razão a um analista como Michael Parenti, que enxerga na Guerra do Kossovo apenas a ambição capitalista de eliminar a todo custo os últimos resquícios de economias estatais no mundo "globalizado". ${ }^{17}$ Ou endossar o entendimento do "subversivo" norte-americano Noam Chomsky, 
com interpretação parecida à de seu compatriota Parenti, menos voltada para o imperialismo econômico do que para o exercício do poder esmagador do Ocidente, orquestrado pela única Grande Potência, contra qualquer resistência a sua dominação. ${ }^{18}$ Nem é necessário levar em conta a massa de escritos críticos à ação aliada amplamente divulgados nos Estados Unidos, inclusive pela grande imprensa, mas somente após os ataques da OTAN e o fim da Guerra do Kossovo, para compreender que o "novo internacionalismo" (na expressão de Tony Blair), ou "novo humanismo militar" (na expressão do alemão Ulrich Beck, apropriada por Chomsky ${ }^{19}$ ), é, no mínimo, controverso. ${ }^{20}$

Independentemente de outros fatores possivelmente influentes, a Guerra do Kossovo, nos termos em que se desenrolou, ocorreu porque havia no Ocidente o sentimento de que "alguma coisa precisava ser feita"; de que os Estados Unidos e a Europa Atlântica não poderiam continuar apáticos ante a previsivel repetição do "fenômeno bósnio", com tudo o que ele acarretara de violência e barbárie em pleno território europeu; de que a Europa altaneira, como berço do Ocidente, e seu filho mais poderoso não poderiam deixar para a ONU a tarefa de impor pela força a arrumação da própria casa - e, com ela, na medida do possível, o respeito aos direitos humanos, de origem histórica reconhecida na cultura euro-norte-americana. Ou, ainda no dizer do Primeiro Ministro Tony Blair, porque “(N)o seu qüinquagésimo aniversário, a OTAN precisa(va) prevalecer”. ${ }^{21}$

À luz, porém, dos resultados obtidos pelos bombardeios maciços para os iugoslavos inocentes, muitos dos quais previamente vítimas de "limpezas étnicas" em outras regiões iugoslavas onde sempre haviam vivido, habitantes de um país destroçado, com o PIB reduzido a menos da metade e desemprego de $50 \%$, onde as pessoas morriam - e, talvez, ainda morram, neste início de século, em conseqüência da guerra - de simples pneumonia, por falta de medicamentos e assistência sanitária; ${ }^{22}$ à luz também da incapacidade que os ocupantes da aliança atlântica e os representantes da ONU vêm demonstrando para transformar o Kossovo numa província administrável; diante, finalmente, das ações armadas que os insurretos albaneses logo passaram a praticar na República da Macedônia e nas vizinhanças sérvias do Kossovo ocupado pela OTAN, não resta a menor dúvida de que essa faceta da "normatividade emergente sobre os direitos humanos", a que se refere Slavoj Zizek, parece, com efeito, produzir seu contrário.

Cabe agora verificar se essa afirmação do filósofo esloveno não se aplicaria igualmente a outras situações, menos bélicas e mais comuns, atinentes aos direitos humanos de todos.

\section{Os violadores democráticos}

Quando, em abril de 2001, pela enésima vez, a Comissão dos Direitos Humanos das Nações Unidas, em Genebra, aprovou, com apoio de quatro países 
latino-americanos membros da Comissão (mas não da Venezuela de Hugo Chávez, que votou contra, nem do Brasil, da Colômbia, do Equador e do México, que se abstiveram), sua resolução (quase) anual condenatória da situação dos direitos humanos em Cuba, tradicionalmente impulsionada pelos Estados Unidos, Fidel Castro, mais uma vez, extravazou sua indignação. Chamou desta feita os latinoamericanos que condenaram seu regime de "lacaios de seu General-em-Chefe" (no caso, o General da reserva e Secretário de Estado norte-americano Colin Powell, que, segundo noticiado, teria feito lobbying para que a região votasse a favor da resolução - aprovada em votação por 22 a 20). Até aí nada de novo e nada de especial. Tampouco foi minimamente original a afirmação cubana, reproduzida pela Associated Press, de que a ilha socialista do Caribe respeita os direitos humanos de seus cidadãos assegurando-lhes sobretudo saúde e outros serviços sociais gratuitos. Mais interessante, embora não propriamente nova, e digna de avaliação aprofundada, foi a insistência também cubana de que Cuba estaria livre das violações mais grosseiras de direitos humanos, inclusive as torturas, “desaparecimentos” e execuções extrajudiciais, que infestam os demais países latino-americanos. ${ }^{23}$

Evidentemente, essas violações mais repulsivas de direitos humanos antes perpetradas pelos regimes autoritários da América Latina ao abrigo da famosa doutrina da segurança nacional, quando não endossadas pelo Estado, são mais facilmente evitadas num país insular e controlador com as dimensões de Cuba do que em territórios continentais extensos, com grande população e fraca capacidade de controle. Não causa, portanto, surpresa, que Cuba, pelo menos por esse aspecto, alegue e, talvez, possa ter registro melhor do que muitos dos demais países latinoamericanos, de regime político democrático e sistema eleitoral pluripartidário. Até porque, em se tratando de país estreitamente monitorado de dentro e do exterior por uma infinidade de ONGs e indivíduos, além de um Relator Especial das Nações Unidas para sua situação, seria absurdo e expletivo que o Governo cubano, com mecanismos de controle estrito sobre seus agentes e a sociedade como um todo, ainda que hipotética e improvavelmente o quisesse, coonestasse esse tipo de brutalidades chocantes.

É fato que quase todos os demais países do hemisfério (e não apenas latino-americanos e caribenhos), em gradações diferentes, ainda registram episódios freqüentes de tortura e execuções sumárias por agentes estatais, por mais que os “desaparecimentos", salvo um ou outro caso, geralmente em situações de insurgência (como a da Colômbia atual ou do Peru de Fujimori), tenham-se transformado, do fenômeno repressivo original, de responsabilidade do Estado, em delitos - igualmente brutais - da criminalidade comum, na forma tão difundida de seqüestros para extorsão. No que diz respeito às duas outras formas de violações mais grosseiras persistentes - torturas e execuções sumárias - ou demais atos de 
arbitrariedade praticados pelos agentes do Poder, o que visivelmente mudou face ao "anos de chumbo" foram, sobretudo, a motivação, geralmente não mais política, assim como o tipo de vítima, não mais propriamente o opositor ideológico, plenamente legitimado nos sistemas democráticos, mas sim, quase sempre, o praticante ou suspeito da prática de crime comum. E nisso vão influir toda a gama de preconceitos vigentes nas respectivas sociedades e, conseqüentemente, presentes na cabeça dos que praticam tais violações.

Não se quer aqui dizer que antes não havia agressões contra criminosos ou cidadãos inocentes suspeitos de crimes comuns, muitas vezes, como sempre, em função de meros estereótipos sociais. Nem se pretende elidir o aspecto político de que se reveste na atualidade, por exemplo, o excesso de força, algumas vezes mortal, aplicado na evicção de sem-terras de áreas sob ocupação. Sabe-se, sim, que as vítimas de arbitrariedades estatais decorrentes de ações e convicções políticas tinham, nas ditaduras, maior visibilidade e apoio internacional do que as vítimas enquadradas na criminalidade comum. De qualquer forma, mudanças houve, para melhor, com a redemocratização. Havendo deixado de configurar políticas de Estado, ou práticas investigatórias/punitivas legalmente toleradas, as agressões de agentes estatais contra a integridade física (às vezes também patrimonial) das pessoas atualmente decorrem, sobretudo, da incapacidade dos Governos centrais para fazer valer suas determinações, seja na sociedade como um todo, seja entre os responsáveis pela execução das leis vigentes (agentes do policiamento ostensivo, delegados, investigadores, comandantes de operações de captura, agentes carcerários etc.). Afinal, quando democraticamente estabelecidas, as normas são supostamente igualitárias e idealmente obedientes aos padrões internacionais.

Pareceria, assim, que, na época presente, as violações "tradicionais”24 mais grosseiras de direitos civis, “de primeira geração” (à não-discriminação, à segurança pessoal, de não ser submetido a tortura ou a detenção arbitrária, à presunção de inocência, à liberdade de locomoção e, até, à propriedade, ${ }^{25}$ para as camadas mais pobres), antes típicas das ditaduras, de direita e de esquerda, tendem a ocorrer com maior frequiência justamente em países de regime democrático e sistema representativo. Com os governos autoritários permaneceriam particularmente as violações de direitos políticos e liberdades fundamentais (de expressão, de associação, de religião), a que se associam, quase sempre, brutalidades físicas não enquadradas propriamente nas definições jurídicas internacionais de tortura (estabelecida no Artigo $1^{\circ}$ da Convenção Contra a Tortura e Outros Tratamentos ou Penas Cruéis, Desumanos ou Degradantes, de 1984), desaparecimento (constante do terceiro parágrafo preambular da Declaração sobre a Proteção de Todas as Pessoas contra Desaparecimentos Forçados, de 1992), ou execuções extrajudiciais (fixadas nas regras de trabalho do Relator das Nações Unidas para Execuções Extrajudiciais, Sumárias ou Arbitrárias). ${ }^{26}$ 


\section{A democracia como violadora?}

É claro que as maiores violações de direitos humanos de todos os tipos, perpetradas pelo Estado, continuam a ocorrer em ditaduras ou países de regime autoritário, secular ou religioso. Conforme estabelecia a Declaração e Programa de Ação de Viena de 1993, a democracia é elemento fundamental para se obter a observância dos direitos humanos, inclusive os “de segunda geração". Até porque, conforme ensinava Marshall desde a década de 40, os direitos civis e políticos sempre foram instrumentos importantes para a consecução dos direitos econômicos e sociais pelo proletariado dos países que se modernizaram nos dois últimos séculos. ${ }^{27}$ Mas, para quem acompanha apenas superficialmente a questão dos direitos fundamentais nestes tempos pós-Guerra Fria, dada a acentuada assertividade dos movimentos da sociedade civil, a total liberdade dos partidos de oposição e a extraordinária - e salutar - exposição autocrítica das mazelas nacionais a que se dedicam os mais importantes órgãos da imprensa livre (quando não-submetida pelo sistema econômico dominante a verdadeira lavagem cerebral, como se vê em alguns dos países ocidentais desenvolvidos), tem-se a impressão de que países como o Brasil, o Chile, a Argentina, a Venezuela e outros congêneres, plenamente redemocratizados neste início de século, são mais violadores dos direitos de sua população do que governos autoritários ignorados dos noticiários.

Diante dessas observações e tomada em seu sentido literal mais primário, a frase de Slavoj Zizek "a normatividade emergente para os direitos humanos é $a$ forma em que aparece seu exato oposto" tenderia a adequar-se também, e sobretudo, às violações persistentes de direitos fundamentais em tempos de paz, denunciadas nas democracias. Pretenderia Zizek, nessas circunstâncias, afirmar que a democracia é mais propensa a violar direitos humanos do que os regimes autoritários? É evidente que não. Pensador profundo e abrangente, por mais descrente do consenso neo-liberal e das deturpações por ele provocadas na percepção contemporânea do sentido da democracia, o filósofo-psicanalista de Ljubljana jamais pretenderia afirmar com sua frase de impacto algo tão incorreto. Até porque o sentiu na própria pele de ex-cidadão iugoslavo sob o regime de Tito, ele sabe (e diz em diversas passagens do mesmo livro) que o autoritaritarismo é mais eficiente apenas no controle policial e demagógico da sociedade. ${ }^{28}$

Deixando novamente Zizek de lado, o que não parece facilmente evidente é, em certos casos específicos, a escassez de meios de que dispõem os países democráticos em desenvolvimento para fazer valer a igualdade e a justiça previstas na legislação doméstica. $O$ que não se torna imediatamente evidente é como, na falta de políticas distributivas adequadas, capazes de minorar a exclusão crescente e os desníveis sociais mais acentuados em tempos de neoliberalismo, os Estados democráticos de qualquer nível de desenvolvimento tendem a recorrer, em todos 
os continentes, a práticas e normas anti-criminais de "tolerância zero". É, por outro lado, evidente e comprovado - além de claramente associado ao significado mais profundo da frase de Zizek - que, ao adotarem as normas penais da "tolerância zero" na esfera criminal (em que se inclui a experiência fluminense da "gratificação faroeste", com seu "stakhanovismo" aplicado à eliminação de marginais), sem resolverem os problemas sociais mais profundos das respectivas sociedades, os Estados democráticos desenvolvidos e subdesenvolvidos propiciam o incremento de abusos de direitos humanos por parte de agentes da polícia e de membros do judiciário contra setores populacionais vítimas de discriminação e estereótipos.

Viena foi bastante clara ao estabelecer, pela primeira vez, o nexo entre a democracia, o desenvolvimento e os direitos humanos. Fê-lo no artigo $8^{\circ}$, nos seguintes termos, canhestros mas inquestionáveis:

"A democracia, o desenvolvimento e o respeito pelos direitos humanos e liberdades fundamentais são conceitos interdependentes que se reforçam mutuamente. A democracia se baseia na vontade livremente expressa pelo povo de determinar seus próprios sistemas políticos, econômicos, sociais e culturais e em sua plena participação em todos os aspectos de sua vida. Nesse contexto, a promoção e proteção dos direitos humanos e liberdades fundamentais, em níveis nacional e internacional, devem ser universais e incondicionais. A comunidade internacional deve apoiar o fortalecimento e a promoção da democracia e o desenvolvimento e o respeito aos direitos humanos e liberdades fundamentais no mundo inteiro."

O que, sem dúvida, não foi corretamente assimilado na prática internacional, assim como nas normas de muitos Estados que se dispõem a aplicar na jurisdição doméstica as disposições da Declaração Universal dos Direitos Humanos e dos Pactos e Convenções internacionais vigentes sobre a matéria, é que todos os direitos humanos, definidos pela ONU desde de 1948 e reafirmados em sua validade universal pela Conferência de Viena de 1993, são “... indivisíveis, interdependentes e interrelacionados” (artigo $5^{\circ}$ da Declaração de Viena). Dada essa característica intrínseca, única capaz de conferir-lhes legitimidade consensual (acima das divergências entre os ensinamentos de Locke e Marx), transversalidade política (ou seja, adaptabilidade às posturas não-radicais da Direita e da Esquerda) e validade multicultural (acima das diferenças de religiões e tradições), por mais que esses direitos “inalienáveis” existam no papel e na intenção de regimes democráticos, não há dúvida de que tais direitos civis e políticos se relativizam. Além de os primeiros serem facilmente deturpáveis, os segundos perdem substancialmente a capacidade de promover transformações efetivas, onde as disparidades de sempre e o neoliberalismo atual não permitem a realização dos direitos econômicos e sociais. 


\section{A indivisibilidade dos direitos humanos e a parcialidade das normas aplicadas}

Em 1968, quando a herança keynesiana do "New Deal” nos Estados Unidos e a social-democracia dos "trinta anos gloriosos" na Europa enfrentavam a competição do comunismo, o radicalismo da Nova Esquerda e as postulações econômicas ultra-liberais de pensadores como Hayek e Milton Friedman, mas, no âmbito planetário, a democracia sucumbia ante golpes militares e movimentos guerrilheiros, a primeira Conferência Internacional sobre Direitos Humanos, realizada em Teerã (a Teerã do Xá Rheza Pahlevi), afirmava, sem ambigüidades, no artigo 13 de sua Proclamação:

"Como os direitos humanos e liberdades fundamentais são indivisíveis, a plena realização dos direitos civis e políticos sem o gozo dos direitos econômicos, sociais e culturais é impossível. O alcance de progresso duradouro na implementação dos direitos humanos depende de políticas nacionais e internacionais saudáveis e eficazes de desenvolvimento econômico e social."

De significado inquestionável para qualquer leitor bem-intencionado, o artigo 13 da Proclamação de Teerã, mais do que uma asserção socialista contra o liberalismo capitalista, ou a definição da social-democracia como meta programática de todos, refletia, em especial, a reinvidicação de uma Nova Ordem Econômica Internacional pelos países do Terceiro Mundo, com respaldo do Segundo, então dada como válida. Foi, aliás, essa rationale estritamente internacional que, com boa dose de hipocrisia, justificou - e ainda justifica, de maneira menos convincente - a defesa calorosa dos direitos econômicos, sociais e culturais no discurso de governos que nada faziam, nem pretendiam fazer, para a redistribuição da riqueza nacional, ou para promover a elevação preferencial do nível de vida dos segmentos mais pobres de sua população.

Além dessa distorção de origem, o artigo 13 revelou-se, logo após sua aprovação, não somente uma afirmação inconsistente com as políticas internas da maioria dos países que o citavam, mas também, e sobretudo, uma escusa lamentável, utilizada por toda e qualquer ditadura - e os regimes ditatoriais eram particularmente abundantes no período - para a denegação dos direitos civis e políticos à respectiva população. Na medida em que a melhor distribuição internacional da riqueza não se realizava e a maioria dos países não tinha condições para atender os direitos econômicos e sociais de seu povo, os governos autoritários e regimes totalitários entendiam não precisarem observar os direitos civis e políticos. Afirmavam, ao contrário, que a supressão destes era condição necessária à implementação das políticas desenvolvimentistas que assegurariam os direitos econômicos, sociais e culturais de todos os cidadãos. Somente depois do atendimento desses direitos “de 
segunda geração”, que exigem prestações positivas de parte do Estado e por isso são considerados direitos de realização progressiva, caber-lhes-ia reconhecer os direitos "capitalistas e burgueses”, segundo Marx, ou "de primeira geração" (conforme a doutrina corrente inspirada nas etapas históricas do estabelecimento das diferentes categorias dos direitos fundamentais).

Foi em razão desse abuso interpretativo do artigo 13 e de seu mal-uso obsessivo por governos ditatoriais que a Proclamação de Teerã tornou-se voluntariamente "esquecida” por todos os militantes mais sérios dos direitos e liberdades fundamentais, governamentais e não-governamentais. Permaneceu, assim, no ostracismo, omitida das relações de documentos internacionais considerados importantes na matéria até a década de 90, e ainda é geralmente desconhecida. Por essa mesma razão, a segunda Conferência Mundial sobre Direitos Humanos, realizada em Viena, em 1993, foi muito mais sutil ao tratar do assunto.

A questão da indivisibilidade e interdependência de todos os direitos humanos é abordada em diversos dispositivos da Declaração e Programa de Ação de Viena. O primeiro que a isso se refere ostensivamente é o artigo $5^{\circ}$, já mencionado acima, que reza:

“Todos os direitos humanos são universais, indivisíveis e inter-relacionados. A comunidade internacional deve tratar os direitos humanos globalmente de forma justa e eqüitativa, em pé de igualdade e com a mesma ênfase. As particularidades nacionais e regionais devem ser levadas em consideração, assim como os diversos contextos históricos, culturais e religiosos, mas é dever dos Estados promover e proteger todos os direitos humanos e liberdades fundamentais, independentemente de seus sistemas políticos, econômicos e culturais”.

Aparentemente contraditório e por isso criticado pelas organizações nãogovernamentais e alguns governos do Ocidente, assim como por observadores acadêmicos que não haviam participado das negociações, o artigo $5^{\circ}$ foi a fórmula, inegavelmente confusa, encontrada para fazer face ao relativismo das posições arraigadamente culturalistas, típicas da década de 90, a que se aferravam com obstinação e agressividade muitos países do Oriente - intelectualmente justificados pelas teorias ocidentais pós-modernas, crescentemente absorvidas por instituições acadêmicas, nem sempre libertárias, de todo mundo. A fórmula se torna mais clara, ou, pelo menos, menos ambígua, quando lida em conjunção com o artigo $1^{\circ}$ da mesma Declaração, que diz:

“A Conferência Mundial sobre Direitos Humanos reafirma o compromisso solene de todos os Estados de promover o respeito universal e a observância e proteção de todos os direitos humanos e liberdades fundamentais de todos, em conformidade com a Carta das Nações Unidas, outros instrumentos relacionados aos direitos 
humanos e o direito internacional. A natureza universal desses direitos não admite dúvidas.

Nesse contexto, o fortalecimento da cooperação internacional na área dos direitos humanos é essencial para a plena realização dos propósitos das Nações Unidas.

Os direitos humanos e as liberdades fundamentais são direitos originais de todos os seres humanos; sua proteção e promoção são responsabilidades primordiais dos Estados.”

Numa fase histórica em que a idéia-meta de uma Nova Ordem Econômica Internacional já se encontrava sepultada, mas o neoliberalismo ainda não ostentava tão visivelmente como agora a figura emblemática dos excluídos (do mercado e da sociedade), nem havia provocado as grandes crises econômico-financeiras iniciadas no México, em 1994, a idéia da "cooperação internacional na área dos direitos humanos para a plena realização dos propósitos das Nações Unidas” soava razoavelmente plausível. Mas Viena foi muito além. No artigo 10 da Declaração de 1993, cuja redação tornou consensual - conquanto efemeramente - o direito ao desenvolvimento, ela estabeleceu clara resposta revogatória, idealmente superadora, ao artigo 13 da Proclamação de Teerã, ao dizer:

“A Conferência Mundial sobre Direitos Humanos reafirma o direito ao desenvolvimento, conforme estabelecido na Declaração sobre o Direito ao Desenvolvimento, como um direito universal e inalienável e parte integrante dos direitos humanos fundamentais.

Como afirma a Declaração sobre o Direito ao Desenvolvimento, a pessoa humana é o sujeito central do desenvolvimento.

Embora o desenvolvimento facilite a realização de todos os direitos humanos, a falta de desenvolvimento não poderá ser invocada como justificativa para se limitarem direitos humanos internacionalmente reconhecidos.

Os Estados devem cooperar uns com os outros para garantir o desenvolvimento e eliminar obstáculos ao mesmo. A comunidade internacional deve promover uma cooperação internacional eficaz visando à realização do direito ao desenvolvimento e à eliminação de obstáculos ao desenvolvimento.

O progresso duradouro necessário à realização do direito ao desenvolvimento exige políticas eficazes de desenvolvimento em nível nacional, bem como relações econômicas eqüitativas e um ambiente econômico favorável em nível internacional."

A solução encontrada por Viena para as distorções propiciadas por Teerã parecia apropriada às melhores tendências do momento. Recorria à linguagem eticamente cogente dos direitos humanos (particularmente forte no pós-Guerra Fria até meados dos anos 90), para afirmar, sem o chavão desgastado da Nova Ordem Econômica Internacional, a necessidade de desenvolvimento como um direito 
fundamental. Rejeitava a manipulação da indivisibilidade dos direitos feita por governos ditatoriais, objetando a invocação da falta de desenvolvimento como escusa para a supressão de quaisquer direitos (subentendendo-se em especial os direitos civis e políticos, de realização supostamente mais fácil). Utilizava-se da atmosfera ainda otimista do fim da bipolaridade estratégica para propor a cooperação entre os Estados na superação de obstáculos ao desenvolvimento. Aproveitava a emergência das organizações não-governamentais como atores internacionais relevantes, assim como o clima anti-estatista facilitado pelo fim do "socialismo real” (sem falar no impulso dado pelo individualismo crescente e pelo neoliberalismo espraiante), para declarar, com razão, que o desenvolvimento tem por sujeito não o Estado, mas a pessoa humana.

O que o humanismo otimista de Viena não levava em conta - não o poderia fazer até porque iria contra a idéia de direitos fundamentais garantidos primordialmente pelo Estado nacional - era a aceleração do processo planetário de globalização econômica, com a liberdade de mercado colocada acima das fronteiras e, conseqüentemente, das possíveis considerações sociais dos diferentes governos, em suas jurisdições territoriais. E que nas condições ideológicas do neoliberalismo mundializado, onde até mesmo os países “socialistas” remanescentes, ademais da sociais-democracias institucionalizadas, defendem o "risco" como elemento salutar à sociedade contemporânea, ${ }^{29}$ o Pacto Internacional de Direitos Econômicos, Sociais e Culturais (assim como os artigos da Declaração Universal dos Direitos Humanos a eles referentes) acaba perdendo o sentido.

Tendo sido sempre encarado em nível inferior a seu homólogo regulamentador dos direitos civis e políticos (e os dispositivos da Declaração que os estabelecem) pelo Ocidente desenvolvido, pelos militantes de direitos humanos de todos os quadrantes e, como conseqüência disso, pelas próprias Nações Unidas, ${ }^{30}$ o Pacto Internacional sobre Direitos Econômicos, Sociais e Culturais, na qualidade de instrumento normativo, caiu, de certa forma, em ostracismo ainda maior do que a Proclamação de Teerã. Esta demonstrou-se recentemente útil pelo menos na luta das mulheres pelo reconhecimento internacional de seus direitos reprodutivos, a serem protegidos pelos Estados por meio da educação e do atendimento às necessidades básicas da saúde sexual feminina. Voltou, por isso, a ser citada como documento referencial importante. ${ }^{31}$

Diferentemente do ocorrido com a Proclamação de Teerã até a década de 90, o Pacto Internacional sobre Direitos Econômicos, Sociais e Culturais não se encontra exatamente esquecido, nem é regularmente omitido da relação dos instrumentos reputados mais importantes na área dos direitos humanos. Seu órgão de monitoramento, o Comitê dos Direitos Econômicos, Sociais e Culturais reúnese com regularidade para examinar os relatórios que lhe são submetidos pelos Estados-partes periodicamente. O Pacto se encontra, na verdade, mais apropriadamente "mumificado". Na qualidade de instrumento jurídico vigente, 
teoricamente cogente para os Estados-partes, não formalmente ab-rogado, funciona como um cadáver antigo, reminiscente de outros tempos mais idealistas (ainda que concretamente cruéis), preservado e observável a título de curiosidade acadêmica, sem valor normativo. Com raríssimas exceções, de países socialmente muito equilibrados (como os nórdicos, até algum tempo atrás), ou para alguns dispositivos limitados, que ainda se busca atender (como na área da educação primária e de algumas esferas da saúde, mais especificamente na campanha contra a AIDS, em que o caso brasileiro tem sido apontado como exemplo), ele não tem, na prática, condições de ser minimamente implementado.

\section{Neoliberalismo versus direitos humanos}

É fato conhecido e dissecado que o neoliberalismo "racionalizante” ora vigente na escala planetária, ademais de produzir desemprego estrutural e de induzir ao desmantelamento das instituições da previdência social - construídas pouco a pouco, com diferentes graus de eficiência, nos mais diversos Estados - encara o mercado como único elemento organizador das sociedades.

No mundo globalizado atual, organizado com base na liberdade econômica absoluta, onde a legitimidade das políticas é dada pelo FMI, bancos e bolsas de valores, o Estado pouco mais pode fazer do que tentar administrar o funcionamento da sociedade para o sucesso das empresas, nacionais e transnacionais. Destituído até mesmo de meios fiscais para operar políticas públicas adequadas, vêem-se os governos cada dia menos capazes de zelar pelo bem-estar geral. Daí recorrerem crescentemente, conforme o modelo norte-americano, à filantropia privada e ao chamado "terceiro setor", das organizações não-governamentais, de direito privado mas com objetivos públicos, para o atendimento paliativo aos indivíduos e comunidades mais carentes. Geralmente o êxito é limitado, já que os demais países não têm a formação histórica eminentemente comunitária dos Estados Unidos, evidenciada até hoje na massa gigantesca de instituições, associações e práticas de vizinhança norte-americanas, dedicadas aos fins mais variados. Isso sem falar na "filantropia" dos abatimentos no imposto de renda, que podem ou não ser muito úteis para setores específicos, mas reduzem ainda mais a arrecadação de fundos para a aplicação em políticas universalistas, voltadas para toda a população.

Com o Estado nacional inerme, inelutavelmente enfraquecido, o recurso às entidades não-governamentais é, evidentemente, válido e necessário - para não dizer imprescindível - até porque, em princípio, não parece haver alternativa. Mas, tendo em conta que o Direito sempre foi um atributo do Estado territorial - que dele se servia inclusive para criar o Direito Internacional -, cabendo a esse mesmo Estado a responsabilidade pela definição normativa interna, a observância das normas pertinentes e a implementação das prestações necessárias aos direitos humanos, a realização dos direitos individuais e coletivos apenas pela ação não- 
estatal, ainda que bem-sucedida, abandona a esfera do jurídico para entrar no domínio da ética e da filantropia. Os direitos deixam, pois, de ser direitos.

Isso não quer dizer ainda que a normatividade dos direitos humanos os transforma em seu contrário: a ausência de direitos. Tal transformação só ocorre quando, no dizer de Jürgen Habermas, o Estado (idealmente) "social-democrata” - ou seja, o Estado com compromisso de organização da sociedade, que não precisa necessariamente ostentar o rótulo formal da social-democracia - opta por ser tão somente um Estado economicamente "liberal”, cuja preocupação única consiste em fazer as condições de seu território atraentes para investimentos, propícias à expansão econômica. ${ }^{32}$ Nessas circunstâncias, a insistência normativa da Conferência de Viena na democracia como condição essencial para os direitos humanos, pareceria hipostasiar a forma da democracia como um disfarce legitimador para o arbítrio do capital, com produção e abandono de excluídos em número sempre crescentes, sem direitos no sentido real do termo. Ou, pior, como recorda ainda Habermas, usando formulação de Anatole France, ao descartar a indivisibilidade dos direitos econômico-sociais, essa democracia “pós-política” (a expressão é de Zizek, significando a democracia que, ao invés de administrar antagonismos, busca obsessivamente um consenso alienante) reduziria a igualdade de direitos ao "direito de cada um de dormir embaixo de pontes". ${ }^{33}$

Num sistema em que as normas da economia derrubam o direito ao trabalho e o Direito do Trabalho; em que a eficiência econômica impõe o desmanche da segurança social; em que as leis do mercado são as únicas existentes para regular a sociedade, cabendo aos pobres a responsabilidade pela própria pobreza, aos marginalizados a miséria absoluta, ou o crime e a penitenciária; em que o ideal da social-democracia dá lugar por completo à aceitação do "risco" e à competitividade, a afirmação de Zizek na epígrafe deste ensaio tende a adquirir ampla validade. A nova normatividade emergente, mas ainda não estabelecida, para os direitos humanos, com ênfase numa democracia sem prestações positivas, sabidamente necessárias para a realização dos próprios “direitos negativos”, ${ }^{34}$ é a forma em que se apresenta seu contrário: a inexistência real de direitos, inclusive os civis e políticos. Faz-se, portanto, necessário lutar para que essa normatividade emergente não se convalide, tonando-se definitiva.

\section{Conclusão: recapitulação e saídas}

Se, conforme já visto neste texto, o otimismo plausível até o Onze de Setembro era todo baseado na vertente exclusivamente punitiva do Direito Internacional recente - vertente necessária, mas não única - na área dos direitos humanos; se a ingerência internacional humanitária tem sido decidida por normas seletivas, agora estabelecidas unilateralmente numa aliança militar; se esse autooutorgado direito de ingerência com motivações humanitárias (legitimado muitas 
vezes a posteriori e a contragosto pela única instância universal existente - as Nações Unidas) é capaz de destruir as condições de sobrevivência de quem nada tem a ver com as atrocidades perpetradas; se os países democráticos se tornam o locus das violações de direitos humanos mais denunciadas; se a "tolerância zero" se transforma em panacéia distorcida para a contenção de marginalizados sociais; se a democracia "pós-política" (sem divergências de classe) das sociedades "pósmodernas" (multiculturalistas, mas anti-universalistas porque hipervalorativas do microcomunitarismo identitário) se auto-satisfaz com a realização de eleições (cujas opções são em geral inexpressivas); se, em resumo, os Estados democráticos aceitam, sem buscarem alternativas, deixar ao mercado a regulação do social, e à filantropia a atenuação da falta de direitos econômicos, a frase impactante de Zizek soa mais do que pertinente: ela se torna factual e descritiva.

Isso não quer dizer que Zizek recomende a aceitação do status quo. Todo o livro do qual se extraiu o trecho inspirador destas linhas é uma apologia do "retorno à Política”, da necessidade de superação do identitarismo pós-moderno no resgate das grandes causas iluministas da emancipação e da democracia, com os direitos humanos, na direção do progresso societário, não necessariamente tecnológico ou econômico. O totalitarismo a que ele se refere inclusive no título - Alguém falou em totalitaritarismo? Cinco interpretações do (mau) uso de uma noção - é uma denúncia veemente à passividade dos tempos “pós-políticos”, uma condenação radical à idéia de consensos, evidentemente artificiais ante desequilíbrios gritantes, uma rejeição indignada à doxa neoliberal, que se utiliza da noção de totalitarismo divulgada por Hannah Arendt como um espantalho para afugentar tentativas de mudança contrárias às regras do mercado. ${ }^{35}$

Enquanto Zizek, com recurso a Lacan, propugna por uma atualização do Marx libertário, não liberticida, sem repressões de qualquer tipo, na denúncia dos malefícios disfarçados do capitalismo contemporâneo, e Habermas, também citado acima, mais otimisticamente espera que o mundo intercomunicativo consiga algum dia transformar a política internacional numa política interna social-democrata de abrangência universal, todos os analistas da atualidade, por essas ou por outras vias, reconhecem que o Estado nacional não tem condições de voltar a ser o que era. A solução necessária aos impasses em que nos encontramos precisa ser inventada em formas supranacionais de convivência e solidariedade, possivelmente inspiradas no que a Europa já fez e pode vir a fazer no caminho de uma união federalista, desde que não abandone, no sentido habermasiano da expressão, a social-democracia, antes inseparável do Estado nacional.

Como o fazer, num mundo de tecnologia avançada onde os fundamentalismos religiosos readquirem feições medievais, micronacionalismos assumem táticas sangrentas, a "esquerda” limita seus objetivos ao progresso de grupos específicos e o capitalismo neoliberal provoca disparidades ainda mais absurdas, entre as nações e dentro delas, ninguém sabe indicar com clareza. Intuitivamente, porém, algo 
começa a ser esboçado. É, afinal, isso que demonstram as manifestações populares, praticamente espontâneas, iniciadas em Seattle em 1999, e que no ano 2000 tiveram, em Gênova, sua pior repressão - assim como o primeiro mártir, com a morte registrada por toda a imprensa. E é por serem contra "isso que aí está" que os manifestantes têm sido virulentamente criticados por defensores do status quo.

As manifestações são, sem dúvida, ainda muito confusas. São também muito difusas nos objetivos dos participantes, freqüentemente contraditórios entre si e, às vezes, paradoxais face aos objetivos alegados. Afinal, elas são, por enquanto, essencialmente sintomas: tais como as febres, incômodas, que abatem como doenças, as manifestações reagem a causas muito mais profundas. Têm tido, porém, o mérito de, pelo menos, acabar com a idéia de consenso - neoliberal ou "de Washington”, significando a mesma coisa - até há pouco martelado, com insistência obsessiva, na linguagem economicista, jornalística e até acadêmica, repetida por quase todos. É por elas que, talvez, algum dia, sejam encontradas as saídas para os impasses atuais. Por elas e, com certeza, com os direitos humanos, quase nunca contestados, desde que seu conteúdo venha a readquirir, como conceito e como norma, a indivisibilidade intrínseca.

\section{Pós-conclusão que não chega a ser epílogo, para completar a pré- introdução, que não chegava a ser prefácio}

Em crítica bastante acerba, não à extrema direita, impermeável por definição, mas à esquerda acomodatícia que renunciou a projetos universalistas de mudança social, ao optar pelo identitário e aceitar o capitalismo de mercado como "único jogo existente" (the only game in town), Zizek, na passagem que antecede a epígrafe deste ensaio, dizia:

"Desta perspectiva, até mesmo a defesa neoconservadora de valores tradicionais aparece sob nova luz: como uma reação contrária ao desaparecimento de uma normatividade legal e ética, gradualmente substituída por regulações pragmáticas que coordenam os interesses particulares de grupos diferentes. Esta tese pode parecer paradoxal: não vivemos nós na era dos direitos humanos universais ...?’36

Os fundamentalismos terroristas da atualidade são, evidentemente, manifestações paroxísticas desse neoconservadorismo. Estejam seus alvos em Nova York, Washington ou Riade, em Nairóbi, Jerusalém ou Oklahoma City, os atentados são sempre, em sua negatividade monstruosa, afirmações valorativas. Destróem, matam e aleijam porque se propõem defender, com ética de barbárie, aquilo que está sendo negado pelo sistema vigente, protegido pelo poder.

Ao explicar o neoconservadorismo atual com percepção profunda, chamando atenção para os engodos da nova normatividade emergente, Zizek, 
ademais de descritivo, acabou sendo, também, involuntariamente profético. Afinal, conforme hoje é sabido, os conservadores no poder optaram por combater o neoconservadorismo terrorista com ações, instrumentos e meios, alguns dos quais normativos, que violam ainda mais a universalidade dos direitos humanos.

Os bárbaros incidentes que atingiram os Estados Unidos no trágico Onze de Setembro, horrorizaram o mundo e disseminaram o medo entre todas as pessoas. Produziram, assim, de imediato, solidariedade espontânea sem precedentes, em escala planetária, com o país líder do sistema atual. A solidariedade foi verbalizada inclusive pelos opositores mais ferrenhos da potência norte-americana, independentemente dos respectivos credos políticos, culturais e religiosos (entre os quais, nos primeiros momentos, os talibãs afegãos). As poucas manifestações de júbilo foram, além de destoantes, totalmente expletivas: meros impulsos mecânicos provocados por infortúnios estruturados em grande parte pela até então inexpugnável "Fortaleza América”. Ninguém em sã consciência, no uso daquilo que se entende como razão (no Oriente como no Ocidente), pode ter-se rejubilado com massacre de inocentes de tamanhas proporções. Ninguém pode ter deixado de sentir empatia com aqueles indivíduos comuns, das mais diversas origens, que calharam de estar presentes nas torres e imediações do World Trade Center na hora da destruição. Todos terão sentido que, a partir dessas agressões, não haveria localidades seguras em qualquer área do planeta.

É uma lástima que a solidariedade universal desse momento de dor generalizada não tenha sido aproveitada para o encaminhamento de mudanças sistêmicas, capazes de corrigir o curso distorcido da normatividade imperante. Como tem assinalado, com eloqüência simbólica, Adolfo Perez Esquivel, Prêmio Nobel da Paz pela causa dos direitos humanos, em pregações incômodas feitas nos Estados Unidos, segundo relatório da FAO, no mesmo dia 11 de setembro de 2001, em que morreram mais de 4.000 pessoas nas duas torres de Manhattan, destruídas por ações que todos, com voz unânime, qualificam como atos de terror, morreram também, de fome, 30.615 crianças. ${ }^{37}$

Ao discurso de grandes potências a linguagem de operações bélicas parece sempre agradar. No passado, o Presidente Lyndon Johnson declarou, no âmbito interno norte-americano, uma "guerra contra a pobreza" que não chegou a vingar. A "guerra contra as drogas”, inspiração aparente da "guerra contra o terrorismo", já dura mais de duas décadas e não tem previsão de acabar.

A "guerra contra o terrorismo" é válida como metáfora forte, se significar determinação efetiva de atuar em todos os fronts necessários: políticos, econômicos, militares e sociais. Nos termos exclusivos em que está posta no final de 2001 bombardeios aéreos e outras ações de combate no exterior, operações policiais e investigação indiscriminada de estrangeiros (árabes) na órbita doméstica - ela pode, sem sombra de dúvida, apreender ou eliminar, juntamente com inocentes, elementos integrantes e até muitos dirigentes de organizações terroristas (assim 
como sua precursora contra as drogas logra às vezes eliminar traficantes de maior ou menor expressão). Mas a "guerra contra o terrorismo" conforme vem sendo conduzida jamais erradicará de per si as sementes do fenômeno, que podem voltar a germinar, em qualquer hora e lugar. Longe de produzir as condições sociais imprescindíveis ao florescimento dos direitos humanos, essa guerra tende a reproduzir na Ásia e em outras partes do mundo, uma multiplicidade infinita de Kossovos.

\section{Notas}

1 Did somebody say totalitarianism? Five interpretations in the (mis)use of a notion, Londres e Nova York, Verso, 2001, p. 244-5, minha tradução. O original em inglês diz:

“...do we not live in the era of universal human rights which assert themselves even against state sovereignty,? Was the NATO bombing of Yugoslavia not the first case of military intervention accomplished (or, at least, presenting itself as accomplished) out of pure normative concern, without reference to any 'pathological' politico-economic interest? This newly emerging normativity of 'human rights' is nevertheless the form of appearance of its very opposite."

2 Id., ibid., p. 245.

3 O Governo democrata do Presidente Clinton, já quase certo da derrota eleitoral de seu candidato Al Gore, assinou o estatuto do tribunal de Roma em 31 de dezembro de 2000, em gesto meramente simbólico, ciente de que o Presidente Bush não o encaminharia ao Congresso para aprovação e subseqüente ratificação, dada a conhecida oposição do Partido República e do estamento militar.

4 Barbara Crossette, “Guide proposed for trials of rogue leaders”, The New York Times, 23 jul. 2001, p. A2. Para exame de um caso exemplificativo de delito objeto de jurisdição internacional, v. J. A. Lindgren Alves, A arquitetura internacional dos direitos humanos, São Paulo, FTD, 1997, p. 140-1 (a propósito dos Artigos $5^{\circ}$ a $8^{\circ}$ da Convenção Contra a Tortura e Outros Tratamentos ou Penas Cruéis, Desumanos ou Degradantes).

5 V. sobre o assunto, com apreciações radicalmente opostas, Michael Parenti, To kill a nation the attack on Yugoslavia, Londres e N. York, Verso, 2000, p 127-8 (Parenti conta que, numa segunda investida judicial, em novembro de 1999, dois advogados canadenses chegaram a indiciar nominalmente 67 personalidades da aliança atlântica, sem qualquer resultado prático), e Henry Kissinger, “The pitfalls of international jurisdiction”, Foreign Affairs Vol. $80 n^{\circ}$ 4, jul./ago. 2001, p. 93.

6 A entrega foi feita por decisão do Presidente da Sérvia, Zoran Djindjic, contra a vontade do novo Presidente da Iugoslávia, Vojislav Kostunica (eleito como candidato de oposição a Milosevic, nas eleições do final do ano 2000), ante exigência dos Estados Unidos nesse sentido, afirmada muitas vezes antes e reiterada em julho, em conferência internacional de assistência à Iugoslávia redemocratizada, como condição para a liberação da ajuda econômica de que o país necessitava desesperadamente após os bombardeios da OTAN.

7 A Conferência Mundial sobre Direitos Humanos, realizada em Viena, em 1993 (v. sobre o assunto J.A. Lindgren Alves, Os direitos humanos como tema global, São Paulo e Brasília, Ed. Perspectiva e FUNAG, 1994, p. 28-9).

8 Sobre o anacronismo desse rótulo v. id., ibid., p. .

9 Slavoj Kizek, "Direitos humanos e ética perversa”, Caderno MAIS!, p. 13-14, Folha de S. Paulo, $1 \%$ jul./2001. Esse artigo foi motivado sobretudo pela entrega de Milosevic ao Tribunal da Haia e no momento em que Zizek terminava a leitura de livro, lançado algum tempo antes nos Estados 
Unidos, sobre Henry Kissinger (Christopher Hitchens, The trial of Henry Kissinger, Nova York, Verso), no qual este é qualificado como criminoso de guerra, facilmente imputável, mas na prática intocável pelas cortes internacionais recentemente criadas.

10 Mais conhecida organização não-governamental prestadora de assistência humanitária em áreas de conflito bélico no final do Século XX, ganhadora do Prêmio Nobel da Paz de 1999.

11 Para uma descrição do assunto feita por quem o acompanhou como interessado direto, pela ótica dos prestadores de assistência, v. Bernard Kouchner (ex-diretor dos Médecins sans Frontières), Le malheur des autres, Paris, Editions Odile Jacob, 1991, p. 257-308.

12 A atuação dos Estados perante a ação do Comitê Internacional da Cruz Vermelha, organização de nacionalidade suíça caracterizada pela obrigação de neutralidade absoluta, é regulada pelas Convenções de Genebra de 1949 e seus protocolos adicionais de 1977, que conformam o atual Direito na guerra, ou seja o conjunto de regras jurídicas, formalmente adotadas por quase todos os países, a serem seguidas pelos beligerantes com relação a prisioneiros, náufragos, feridos e populações civis. Em conjunto com a legislação internacional sobre refugiados, esse ramo do Direito adotado em Genebra logo após a Segunda Guerra Mundial, compõe o hoje clássico Direito Internacional Humanitário.

13 Insisto na idéia de caso recente porque muitas das intervenções armadas unilaterais em território alheio se deram com a escusa de proteger populações perseguidas (vide, por exemplo, o caso da Alemanha nazista nos Sudetos tchecos).

14 Ainda que a exacerbação belicosa do micronacionalismo, que existira latente nas seis antigas repúblicas socialistas iugoslavas sem impedir a convivência e a miscigenação, tenha sido praticada com igual virulência por todos os líderes separatistas da região, até mesmo com recurso à revalorização de um passado nazista “independente” (no caso da Croácia). A quem tiver interesse em conhecer exemplos dessas práticas de exaltação fascistóide ultranacionalista dos diversos líderes iugoslavos, em crítica perspicaz, às vezes até saborosa, feita por quem as viu de perto, sentindo-as na própria pele de cidadã croata, recomendo as crônicas jornalísticas de Slavenka Drakulic em Café Europa - Life after communism, N. York, Penguin Books, 1999 (original em inglês, primeira edição em Londres, pela Abacus, 1996).

15 Para que não se confunda minha opinião sobre os fatos ocorridos com uma manifestação de parcialidade pró-Sérvia ou anti-OTAN, registro ter acompanhado com grande desgosto e indignação as denúncias de atrocidades contra os albaneses do Kossovo amplamente divulgadas antes do início dos bombardeios, em 24 de março de 1999. Sei também que, no Kossovo, cerca de 12.000 albaneses morreram e 800.000 partiram em busca de refúgio alhures, sobretudo nas vizinhas Repúblicas da Albânia e da Macedônia (a maioria já retornou). A dúvida que se me colocou desde o início é se os bombardeios aéreos serviriam de dissuasão preemptiva ou de motivação adicional para o agravamento das violações de direitos humanos dos kossovares pelas forças sérvias, quase sempre paramilitares. Segundo a literatura mais séria hoje abundante sobre o assunto, a segunda hipótese configurou-se real.

16 Apud Noam Chomsky, The new military humanism - Lessons from Kosovo, Monroe, Common Courage Press, 1999, p. 3-4, reproduzindo citações em matérias da Newsweek de 19 abr. 1999 e do New York Times de 16 mai. 1999. Minha tradução.

17 Michael Parenti, To kill a nation - The attack on Yugoslavia, Nova York, Verso, 2000. Volitiva ou involuntariamente, a Iugoslávia de Milosevic ainda não se tinha inserido na ética do mercado.

18 Noam Chomsky, op. cit. e "Crisis in the Balkans”, in Rogue states, Cambridge (Massachussetts), V. supra nota 15, p. 4.

20 É aparentemente por isso, e não apenas porque os novos “terroristas”, logo após a Guerra do Kossovo, passaram a ser as antigas vítimas por ela protegidas contra os sérvios, que a OTAN demonstrou-se tão mais cautelosa - e construtiva - na Macedônia.

21 Apud Noam Chomsky, op. cit. nota 15 supra, p. 51. Recorde-se que os 50 anos da OTAN foram celebrados em Washington, em abril de 1999, enquanto ocorria a “limpeza étnica” do Kossovo. 
Foi nessa ocasião que a aliança atlântica enunciou ostensivamente sua nova “doutrina”, de intervenção humanitária, dentro ou fora da Europa.

As cifras aqui reproduzidas, amplamente divulgadas pela imprensa internacional, foram retiradas da matéria “Quanto Mais Ajuda, Pior Fica”, da VEJA, edição 1.708, ano 34, n 27, 11/jul./2001, p. 54-5. A informação sobre a situação sanitária iugoslava no pós-guerra do Kossovo me foi passada no final de 2000 por amigos norte-americanos de origem sérvia, que haviam acabado de visitar parentes no país.

23 Associated Press, “Castro calls Latin countries 'lackeys' for anti-Cuban vote”, San Francisco Chronicle, 27 abr. 2001, p. D3.

24 Na medida em que, para os militantes atuais de movimentos em defesa dos direitos humanos, conforme visão prevalecente na ONU, os desaparecimentos forçados ou involuntários teriam sido uma criação do Cone Sul da América Latina sob os regimes militares dos anos 60 e 70, que se espalhou pelo mundo e se ampliou sobretudo na América Central, reconheço a incongruência de chamá-los de violação tradicional. De qualquer forma, a par de minha descrença na originalidade latino-americana nessa matéria (os tristemente célebres julgamentos de correligionários de Partido e ex-autoridades dos regimes stalinistas sempre se iniciavam com o "desaparecimento" do suposto traidor; o mesmo ocorria nas "batidas" nazi-fascistas contra judeus e opositores do regime), é fato inconteste que os “desaparecimentos” aqui referidos quase sempre se seguiam de outras violações mais "clássicas”, geralmente envolvendo torturas, muitas vezes terminando por execuções.

25 Refiro-me aqui à destruição de barracos e outros bens "patrimoniais” de favelados e sem-terras nas ações policiais, inclusive as mais bem-intencionadas (sem falar, obviamente, das extorsões criminosas feitas pela polícia).

26 A título ilustrativo, v. Bacre Waly Ndiaye, Report of the Special Rapporteur Submitted Pursuant to Commission on Human Rights Resolution 1995/73, documento das Nações Unidas E/CN.4/ 1996/4, 25 jan. 1996, em que o Relator Especial relacionava dez tipos de situações de ameaça ou morte diante das quais procurava intervir para tentar salvar a pessoa ou evitar a repetição da prática.

27 T.H.Marshall, “Citizenship and social class” (1949), in Gerson Shafir, The citizenship debates - a reader, Minneapolis, University of Minnesota Press, 1998, p. 93-111.

28 Embora - e sou eu quem o digo, não Zizek - na maioria daqueles países em que se verificou a “transição" do comunismo totalitário para a democracia capitalista - ou, mais corretamente, de um socialismo torto para o absolutismo neoliberal do mercado -, as novas “máfias” onipresentes e os mendigos ubíquos, antes inexistentes ou simplesmente invisíveis na Europa Oriental, tendam a comprovar que o regime não-democrático anterior era mais eficaz não apenas na esfera da repressão, mas também na área da segurança social da população.

29 V. por exemplo Anthony Giddens, Runaway world - how globalization is reshaping our lives, Nova York, Routledge, 2000, p. 38-53.

30 Basta lembrar, nesse sentido, que o órgão de monitoramento do Pacto Internacional sobre Direitos Civis e Políticos é o único que tem o nome de Comitê dos Direitos Humanos.

31 A Proclamação de Teerã foi exumada e recordada, pela primeira vez depois de muitos anos, pelo movimento feminista, por ter sido o primeiro documento a falar no direito dos pais de controlar volitivamente o número e o espaçamento dos filhos. Foi, assim, mencionada como referência para as questões atinentes à saúde sexual da mulher no parágrafo 41 do Programa de Ação de Viena e voltaria a ser referida como precedente importante nas Conferências do Cairo, em 1994, sobre população e desenvolvimento, e de Beijing (Pequim), em 1995, sobre a situação da mulher. Jürgen Habermas, Après l'État-nation - une nouvelle constellation politique, trad. Rainer Rochlitz, Paris, Paris, Fayard, 2000, passim. 
34 “Direitos negativos” são, doutrinariamente, aqueles que se realizariam pela simples inação - ou "prestação negativa” do Estado - como o direito de não ser torturado, a uma justiça imparcial, etc. Como já tive a oportunidade de explicar alhures, também esses direitos requerem "prestações positivas”, por sinal vultosas (v. J. A. Lindgren Alves, Os direitos humanos como tema global, São Paulo, Perspectiva, 1994, p. 103-116).

35 Slavoj Zizek, op. cit., p. 2-5.

36 Id., ibid. p. 244, minha tradução. O original diz:

"From this perspective, even the neoconservative defense of traditional values appears in a new light: as a reaction against the disappearance of ethical and legal normativity, which is gradually replaced by pragmatic regulations that co-ordinate the particular interests of different groups. This thesis may appear paradoxical: do we not live in the era of universal human rights ....?"

37 Além de me ter passado essa informação pessoalmente, em jantar na Universidade de S.Francisco, Esquivel a tem repetido em conferências feitas nos Estados Unidos em outubro de 2001, algumas das quais televisionadas.

\section{Resumo}

O presente artigo analisa a situação atual dos direitos humanos, guiado pelas afirmações críticas do autor esloveno Slavoj Zizek, quando defende que a nova normatividade emergente para os direitos humanos acaba por ser a forma em que aparece o seu exato oposto. Abarcando os atentados de 11 de setembro, sem que isso se constitua o foco central do estudo, o artigo avalia a validade dessa afirmação ante as vicissitudes empíricas com que os direitos humanos vêm se defrontando nos últimos anos.

\section{Abstract}

The article analyses the current situation of human rights, guided by the critic affirmations of the Slovene author Slavoj Zizek, when he supports that the new emerging normativity of the human rights ends to be the form of appearance of its very opposite. Contemplating the $11^{\text {th }}$ of September, without this constitutes the central focus of the study, the article evaluates the validity of these affirmations the empirical vicissitudes which the human rights have been facing in the last years.

Palavras-chave: Direitos humanos; Direito Internacional Público; Neoliberalismo Key words: Humsn rights; Public International Law; Neoliberalism. 